\title{
Students' Creativity in Project Based Learning
}

\author{
Siti Munawaroh*, Imam Sukwatus Suja'i \\ Magister Program student of Social Science Education \\ Universitas Bhinneka PGRI \\ Tulungagung, Indonesia \\ *munawarohsiti74@gmail.com
}

\author{
Dian Septi Nur Afifah \\ Magister Program of Mathematic Education \\ Universitas Bhinneka PGRI \\ Tulungagung, Indonesia \\ dian.septi@stkippgritulungagung.ac.id
}

\author{
Ika Mariana Putri \\ Mathematics Education \\ Universitas Bhinneka PGRI \\ Tulungagung, Indonesia \\ ikamarianaputri@gmail.com
}

\begin{abstract}
Students interaction with computer is needed to sharpen student skills. However, there are still students who use computer to play games, not for learning. This causes student has not reached the competence that expected. For that, teacher needs to apply project-based learning to assist students learning in order to acquire knowledge and skills that strong and effective. This research aims to determine creative thinking in project based learning in creative product and entrepreneurship subject. This research type is descriptive qualitative research. The subjects in this research were student of IX grade in vocational high school 1 Boyolangu who was determined by purposive sampling. Data collection techniques used includes observation, interview, and documentation. The instrument is researcher himself, the observation sheet and observation guide. Data analysis technique includes interview transcript result, analysis, and triangulation. The result showed that students with high creativity think fluently, able to design project smoothly, have unique ideas, able to solve the problem well. The ability to think flexibly, able to complete project quickly. Original thinking skills able to carry out project and present them attractively. Further, project based learning can be used an alternative to improve students creative thinking.
\end{abstract}

Keywords—creativity, project base learning

\section{INTRODUCTION}

Education is one of the key to success in the future, that has many avantages for people [1]. Education has a role not only in providing educational value that educate students but also educational value that help to shape student's character, include critical thinking and creative thinking. This ability do not just appear naturally but need to be taught and designed at school and college. This ability and skill need to develope in every subject including creative product and entrepreneurship. Provision this skill and ability necessary in class when learning process occur. Learning is a process of helping student to obtain the information idea, skill, value, and the ways how to learn [2]. To develop the skill and potentian in themselves, student has different ability depending on their respective creativity level. The perspective on mathematics creative thinking refers to a combination of logical and divergent thinking which is based on intuition but has a conscious aim [3]. According to Mursidik level of creative thinking is classified as high order competencies and can be viewed as a continuation of basic competencies.

Project based learning or PBL refers to an approach to instruction that teaches curriculum concept through a project espousing principles learner-centered teaching, learner autonomy, collaborative learning and learning through task [4]. Project based learning is an individual or group project that carried out within a certain period of time and produce a product which then displayed or presented [5]. Project based learning is characterised by students' autonomy, constructive investigantion, goal-setting, collaboration, communication and reflection within real-word practice [6]. In general there are seven steps from project based learning, consist of formulating the expected learning outcome, understanding the conept of teaching materials, skill training, designing the project theme, making the proposal, executing the task and presentation the project [7]. Student do exploration, assessment, synthesis, and information to produce various forms of learning outcomes. This project based learning can be said concep operationalizing of Production Based Education" developed in Vocational High School (further reffered as SMK) [8]. The project can be a project of one teacher, or from several teachers who teach different subjects. Students trained to conduct problem analysis, carry out exploration, collect information, interpretation and assessment in working on project related to the problem being studied.

This learning allow student to develop their creativity in designing and creating project that can be used to solve the problem [9]. Project based learning is based on constructivism theory and an active student learning (student center learning). Learning process through $\mathrm{PjBL}$ allows teacher to "learn from 
student" and "learn with student" [10]. Learning through PjBL also can be used as a learning method to develop students' ability in planning, communicatin, problem solving, and making decision. According to Sumarni [11] there are some advantages of the implementation project based learning, there are increase students' learning motivation, academic aachievement, the ability to comunicate, skill in managing learning resources, creativity, attitude toward learning. For this reason, the purpose of this study is to determine creative thinking in project-based learning on creative product and entrepreneurship's learning.

\section{METHODS}

This research type is descriptive with qualitative approach. The research was conducted at vocational high school 1, Tulungagung. Subject criteria selection are student who has high creative ability and good communication skill. Data collection techniques by direct observation in the field, documentation, interviews with XI TKJ 1 homeroom teacher and students and also the head of TKJ department about how the student's creative thinking profile project based learning. Data has been collected from interview, observation, documentation and existing notes than identified to facilitate data analysis. The final stage of this research is presenting data according to the original in the form of a description and analyzing it.

\section{RESULTS}

Vocational High School 1 Boyolangu, Tulungagung is one of the leading school that reference for female students in Tulungagung, where many student has received awards and championships both at district provincial and national level. In this study, researchers will describe the data obtained by researchers from the interview, obervation and documentation result related the study focus.

Researchers chose project based learning model because this learning model was student centered, allowing knowledge sharing between friends and teacher in a relatively short time. In addition, students need to be given the opportunity to collaborate learn with their friends in developing an understanding of important concept and principle. Project based learning model concist of four main stages, namely: (1) the planning stage, (2) the design phase, (3) the implementation stage, (4) the reporting stage. In developing the learning process in the classroom using the creative product and entrepreneurship subject learning model.

Core competencies and basic competencies in PKK subject require students to make a product, so the learning model that teacher feel is most appropriate is project based learning. Where in the learning process students' creative thinking is needed

At project design stage, subject with high gruop creative thinking skills have the ability to think fluently. In addition, it is able to translate the needs that are developing in the community so that idea arise to make product in great demand and sell well in the market, are able to make creative ideas in determining product making ideas and pouring them out. Beside being able to motivate friends in group to participate actively and participate in realizing the project, able to overcome problems that arise when implementing the project, able to generate ideas, answers and various questions, able to see a problem with different direction of thought, be able to change the way they approach or think. Capable of producing unique and new expressions, and capable of making unusual combination of parts of elements.

At project implementation stage, the subject is able to realize the result of his design satisfactorily and able to collaborate in carrying out his project together with his group, able to make works from different angle, in here subject has made innovative work in form of clothing design produced from used material, namely made of coffee wrapper. Beside that, it also able to make the equipment concept from used material to be produced into something different, able to make new idea to make an interesting work and able to solve existing problem, being able to turn used goods into a work of value and power to use

Project reporting stage, the ability to think fluently, in presenting project report, was seen very enthusiastic about listening to presentation from other group and active in asking question [12]. The student able to come up with a lot of answer, idea, problem solving, and question asked. Provides multiple ways or suggestions of things to do and provide more than one answer. The ability to think flexibly, the subject able to make attractive design to presented in front of the class and able to motivate one group to actractive and creative when making presentation in class. Also, when other groups make presentation, they can actively participate in livening up group discussions. Original thinking skill, when providing project reporting, able to combine the thought of friends in group and produce interesting collaboration, so the presentation result always looks alive.

Furthermore, the factors that can support and inhibitor students' cerative thinking, namely the will of the child, the opportunity for children, the opportunities that exist in the job market, the abilities of the child, the availability of tools and practical materials available. Learning media that proper for student to be more creative. Using learning media, children can more enthusiastic than before. As for what teacher use in learning, namely teaching props. Where media is concrete or real can make children more active and creative. Extracurricular is very useful even in line with the curriculum in schools, because the purpose of this extracurricular activity is to enrich the knowledge and skills of students, so they can work and try to do creativity that beneficial to both of themselves and others. Like the extras of graphic design and painting, these an increase student creativity.

While the factor that prevent students who are busy alone in class like to disturb other students in learning. So it causes other student who take part in class learning to be disturbed by student who are busy alone. In addition, students' thought and 
psychological state also the causes of creativity lack. Economic factor also one of the obstacles for student to be creative and the motivation lack both from within and outside of child, technological development that provide instant thing, so it give less motivation in creativity.

\section{DISCUSSION}

A. Students' Creative Thinking Profile in the Implementation Using Project Based Learning Strategies on Creative Product and Entrepreneurship Subjects Based on the $3^{\text {rd }}$ Project Based Learning Steps, According to Sani, Group Make a Project Plan Related to Problem Solving Identified or the Topic Given

The upper group has the ability to think fluently as proven by making project plan that can made quickly and completed with good cooperation, in terms of flexible thinking, the upper group is able to divide their team according the task and ability of their group members as well as to motivate the performance of their group members, while in original thinking skills, the upper group is able to make creativity and innovation design according the imaginative result they do with their group [13].

Based on the fourth project based learning steps, according to Sani, the group cerate project or work by understanding the concept or principle related with the subject matter. The upper group has the ability to think fluently, in this case, the group is able to realize project that carried out according to design and produce excellent work, and effective [14]. For characteristic, flexible creative thinking, the upper group when experiencing problem in realizing the project, this group is able to take alternative choices and be compact in decision making and able to overcome any difficulties that exist. In ability to original think, there is no doubt the shrewdness of think group in teamwork when working on their project. Based on the fifth project based learning steps, according to Sani, the group display the project has been done (presentation). In term of fluent thinking, the upper group is able to make report and present them well and smoothly. For the characterisric of flexible thinking students with high group creativity are able to answer any question asked from othe group and able to overcome obstacles during presentation, for example the use of presentation media and so on. The ability in original thinking of the upper group in making report and presentation was made with very interesting result.

\section{B. Supporing and Inhibiting Factors for Student Cerativity in Project Based Learning in Creative Product and \\ Entrepreneurship at Vocational High School 1 Boyolangu, Tulungagung.}

The supporting factor for student creativity is the willingness of the child, the greater child's ability, the greater leel of creativity. Opportunity children, creativity will emerge when given the opportunity. Opportunity exist in job market, with opportunity, creativity will also triggered to be better. The greater child's ability, the higher level of creativity. Supporting factor for student creativityin teaching and learning process.
This can be seen by the principal who fully support the effort of the teacher in guiding student to be more creative and the serious effort of teacher when explaining learning material with diligence, patience, guiding and motivating student to keep on learning, delivering material using learning media. The delivery of material like this, makes students more attentive and do not clumsy or busy themselves. Besides, using concreate or real learning media can make student excited in participating in learning.

The supporting factor for student creativity do not only come from class lesson but extracurricular activities can also increase children's creativity, such as graphic design and painting, this also include support for the creativity of their parents so that students can be creative and innovative. Extracurricular also can distribute their talents. Encourage children to be involved in school activities and reward children's learning achievement by giving gift or word of praise so that students are excited to be more creative.

\section{Inhibiting Factors for Sudents' Creativity}

When researcher do observation in the learning process, the factor that inhibiting the teacher in increasing student creativity can be seen from the learning prcess, there are some student whose concentration is not good due to several factor include being tired, sleepy at noon, lack of interest in learning, and so on. Other, the lack of active students in the class, sometimes teacher is less atractive in delivering the material or student who do not like learning material, lack of motivation from within themselves and the environment, lack of motivation greatly affects the development of children's potential, achievement and creativity. In addition, the effect of the lack of practical tools in learning causes obstruction of tasks that must be completed and students become reluctant. Lack of motivation both from within and from outside the child, the motivation factor greatly determines the level of student creativity. Technological developments that provide many instant goods so that it does not provide motivation in creating. Children tend to quickly get the desired item without working hard, which also results in laziness and difficulty in creativity.

\section{Strengths and Advantages of Using Project Base Learning Methods}

Project based learning is a comprehensive approach that provides guidance for students, works individually or in groups, and deals with the surrounding environment or topics in the real world [15]. Good PjBL implementation can provide useful abilities for students. The success of PjBL occurs when students are highly motivated, feel active in their learning, and produce high quality work results. Project-based learning model because this learning model is student-centered so that it allows sharing of knowledge between friends and teachers in a relatively short time. In addition, students need to be given the opportunity to learn to collaborate with friends in developing an understanding of important concepts and principles.

Core competencies and basic competencies in PKK subjects require students to make a product, so that the learning 
model that teachers feel is most appropriate is project-based learning. Where in the learning process students' creative thinking is needed.

Here are some of the advantages of using a project-based learning approach: Motivating students by involving them in their learning, leaving them according to their interests, answering questions and making decisions in the learning process. Provide learning opportunities in various disciplines. Help relate to life outside of school, pay attention to the real world, and develop real skills. Provides unique opportunities because educators build relationships with learners, as trainers, facilitators, and co-learners. Provides opportunities to build relationships with a large community. Making students more active and successful in solving complex problems. Encourage students to develop and practice communication skills. Providing experiences to learners learning and practice in organizing projects, and making time allocations and other resources such as equipment to complete tasks. Provide learning experiences that involve students in a complex and designed to develop according to the real world. Making the learning atmosphere fun, so that students and educators enjoy the learning process.

\section{CONCLUSION}

The results showed that students who has upper creativity in thinking fluently, were able to design projects smoothly, had unique ideas, were able to solve problems well. The ability to flexibly think, able to complete projects quickly. Original thinking skills, able to carry out projects and present them attractively. Henceforth, project-based learning can be used as an alternative to improve students' creative thinking.

Factors that support Student Creativity are the willingness of the child, the opportunity for children, creativity will appear when given the opportunity. The opportunities provided, as well as the abilities that children have. Inhibiting Factors for Student Creativity according to the findings are: tired, sleepy, hungry because at noon, they are in an unhappy condition, the students are not active in class, sometimes the teacher is less attractive in delivering material or students who do not like learning material, lack of motivation in itself and the environment, technological developments that provide instant goods so that it does not provide motivation in creating.

\section{REFERENCES}

[1] A. Al Shuaibi, The Importance of Education. Salalah: Salalah College of Technology, 2014.

[2] S. Suparman, Desain Instruksional Modern (Panduan Para Pendidik dan Inovator Pendidikan). Jakarta: Penerbit Erlangga, 2014.

[3] E. Pehkonen, "The state-of-art in mathematical creativity," ZDM, vol. 29, pp. 63-67. 1997

[4] Y.C.G. Mali, "Project-Based Learning in Indonesian EFL Classrooms: from Theory to Practice," IJEE (Indonesian J. English Educ.), vol. 3, no. 1, 2016.

[5] H. Putria, L.H. Maulana, and D.A. Uswatun, "Analisis Proses Pembelajaran Dalam Jaringan (DARING) Masa Pandemi COVID-19 pada Guru Sekolah Dasar," J. Basicedu, vol. 4, no. 4, pp. 861-872, 2020

[6] D. Kokotsaki, V. Menzies, and A. Wiggins, "Project-based learning: A review of the literature. Improving Schools," vol. 19, no. 3, pp. 267-277, 2016.

[7] N. Jalinus and R. azis Nabawi, "The Seven Steps of Project Based Learning Model to Enhance Productive Competences of Vocational Students," Conf. Int. Conf. Technol. Vocat. Teach. (ICTVT 2017), vol. 102, 2017.

[8] Depdiknas, Undang Undang Nomor 20 Tahun 2003 tentang Sistem Pendidikan Nasional. Jakarta: Depdiknas, 2003.

[9] M. Haughey and T. Anderson, Networked learning. The pedagogy of the Internet. Montreal: McGraw-Hill. 1998.

[10] S. Bell, "Project-Based Learning for 21st Century: Skill for the Future. The Clearing House," 2010. [Online]. Available: http://www.teacherscollegesj.org/resources/ publications/PBL for the 21 Century.pdf.

[11] W. Sumarni, "The Strengths and Weaknesses of the Implementation of Project Based Learning: A Review," Int. J. Sci. Res., 2013.

[12] M.E. Gredler, Learning and Instruction: Teori dan Aplikasi terjemahan Tri Wibowo B.S. Jakarta: Kencana Perdana Media Group, 2001.

[13] D. Daryanto and T. Tasrial, Konsep Pembelajaran Kreatif. Yogyakarta: Gava Media, 2012.

[14] S. Dewi and S. Eveline, Mozaik Teknologi Pendidikan. Jakarta: Prenada Media Group, 2008.

[15] H. Harjanto, Perencanaan Pengajaran. Jakarta: Rineka Cipta, 2008. 